\title{
The essence and significance of services provided by internal affairs agencies for remuneration
}

\section{Umida MAKHMUDXODJAYEVA ${ }^{1}$}

Academy of the Ministry of Internal Affairs of the Republic of Uzbekistan

\section{ARTICLE INFO}

\section{Article history:}

Received September 2020

Received in revised form 15

September 2020

Accepted 25 September

2020

Available online

1 October 2020

\section{Keywords:}

Service

Work

Paid services

Activity paid services

\begin{abstract}
The article analyzes the essence and meaning of such concepts as service, work, paid services, activity paid services, and also considers the types of paid services by internal affairs bodies. Also in this direction, the opinions of lawyers and scientific economists on the penetration of new types of services were thoroughly studied, proposals and recommendations were developed.
\end{abstract}

2181-1415/C 2020 in Science LLC.

This is an open access article under the Attribution 4.0 International (CC BY 4.0) license (https://creativecommons.org/licenses/by/4.0/deed.ru)

\section{Ички ишлар органларининг томонидан пуллик асосда хизматларини тақдим этиш ва уларнинг ўзига хос хусусиятлари.}

\section{Калит суцзлар:}

Эксперт-криминалистика,

Пуллик экспертиза

хизмати

Пуллик экспертиза

Хизмати турлари

\begin{abstract}
АННОТАЦИЯ
Мақолада ички ишлар органлариннг эксперткриминалистика булинмалари томонидан хақ эвазига кўрсатиладиган хизматларнинг турлари ва уларнинг ўзига хос хусусиятлари ёритилиб, чет эл тажрибаси тахлил этиб берилди. Шунингдек, хуқуқшунос олимларнинг фикр ва мулохазалари атрофлича ўрганилиб, таклиф ва тавсиялар ишлаб чиқилди.
\end{abstract}

\footnotetext{
${ }^{1}$ Independent researcher Academy of the Ministry of Internal Affairs of the Republic of Uzbekistan email: musanifa-88@mail.ru
} 


\section{Суть и значение услуг, оказываемых органами внутренних дел за вознаграждение}

\section{Ключевые слова:}

Услуга

Работать

Возмездное

оказание услуг

Деятельность

возмездное оказание услуг

\section{АННОТАЦИЯ}

В статье анализируются суть и значение таких понятий, как услуга, работать, возмездное оказание услуг, деятельность возмездное оказание услуг, а также рассматриваются виды платной услуги органами внутренних дел. Также в данном направлении, были изучены мнения юристов и ученых-экономистов о проникновении новых видов услуг, разработаны предложения и рекомендации.

Мамлакатимизда амалга оширилаётган ислохотларнинг пировард мақсади, бу энг аввало, инсонлар учун муносиб турмуш хамда фаолият шароитларини яратишдир. Бу эса ишлаб чиқариш сохалари билан бир қаторда, хизмат курсатиш сохасини хам ривожлантиришни талаб қилади.

Бу борада Ўзбекистон Республикаси Президенти Ш.М.Мирзиёев таъкидлаганидек, тармоқлар ва худудларни модернизация қилиш, уларнинг рақобатдошлик даражасини ошириш, хизматлар сохасини ривожлантириш масалалари доимий эътиборимиз марказида бўлиши лозим. Зеро, хизмат кўрсатиш сохаси иқтисодиётимизни барқарор ривожлантиришнинг энг мухим манбаи ва омили хисобланади.

Маълумки, бугунги кунда республикамизда «хизмат кўрсатиш сохасини жадал ривожлантириш, ялпи ички махсулотни шакллантиришда хизматларнинг ўрни ва улушини ошириш, кўрсатилаётган хизматлар таркибини, энг аввало, уларнинг замонавий юқори технологик турлари хисобига тубдан ўзгартириш» долзарб масала хисобланади. Шу боис бугунги кунда мамлакатимизда барча сохалар каби хизмат кўрсатиш сохасини хам такомиллаштиришга қаратилган туб ислохотлар амалга оширилмоқда.

Натижада кўп сонли иш ўринларини хамда ижтимоий фаровонликни оширишга сабаб бўлаётган хизматлар тури ортиб бормоқда. Жумладан, 2019 йилнинг 1 октябрь холатига кўра, хизматлар сохасида 209,5 минг бирлик корхона ва ташкилотлар фаолият кўрсатган, уларнинг умумий таркибида савдо хизматлари - 33,1 \%, яшаш ва овқатланиш бўйича хизматлар - 9,2 \%, ташиш ва сақлаш - 6,2 \%, ахборот ва алоқа - 3,3 \%, соғлиқни сақлаш - 3,1 \%, ахборот ва алоқа - 3,3 \%, ижтимоий хизматлар кўрсатиш - 3,1\%, бошқа хизмат турлари - 45,1 фоизни ташкил этган.

Айни пайтда, мамлакатимизда барча сохаларда, хусусан ички ишлар органларида хам хақ эвазига хизмат кўрсатиш сохасининг ролини ошириш хамда янги-янги хизмат турларини изчиллик билан тизимга жорий этиш долзарб масалалардан хисобланади. Таъкидлаш жоизки, сўнгги пайтда ички ишлар органларининг сохавий хизматларида хақ эвазига хизмат кўрсатиш сохасини ривожлантиришга қаратилган изчил ислохотлар амалга оширилмоқда. Жумладан, Ўзбекистон Республикаси Президентининг 2017 йил 18 апрелдаги “Ички ишлар органларининг жиноятларни тергов қилиш сохасидаги фаолиятини тубдан такомиллаштириш чора-тадбирлари тўғрисида" ги ПҚ-2898-сонли Қарорига 
мувофиқ Ички ишлар вазирлиги Эксперт-криминалистика бош марказивазирлик марказий аппаратининг бошқарма хуқуқидаги таркибий бўлинмаси сифатида фаолият юритадиган бўлди. Марказга Ўзбекистон Республикаси ИИВ томонидан белгиланадиган тартибда ташкилотларга эксперт-криминалистика фаолияти сохасида пуллик экспертиза, илмий-тадқиқот ва ахборот хизматларини кўрсатиш хуқуқи берилди.Назаримизда, ушбу ваколат Марказ томонидан хизматлар кўрсатиш доирасининг кенгайишига, тизимда илғор криминалистик ва илмийтехник воситаларни хамда ишлашнинг замонавий шакл ва услубларини кенг жорий этилишига олиб келади. Шу билан бирга, фаолият самарадорлигини ошириш, пировардида тергов органларининг фаолиятининг такомиллашувига ёрдам беради.

Жумладан, ИИВ Эксперт-криминалистика бош маркази, Тошкент шахар ички ишлар бош бошқармаси эксперт-криминалистика маркази, Қорақалпоғистон Республикаси ИИВ, вилоятлар ички ишлар бошқармалари эксперткриминалистика бўлимлари, туманлар (шахарлар) ички ишлар бошқармалари (бўлимлари), транспортда жамоат хавфсизлигини таъминлаш бўлимлари эксперткриминалистика бўлимлари (бўлинмалари, гурухлари) томонидан юридик шахсларга пуллик асосда 2017 йилда - 5 та, 2018 йилда -33 та, 2019 йилда - 46 та (жами 43 млн. 282 минг 682 сўм миқдорида) экспертлик, илмий-тадқиқот ва ахборот хизматлари кўрсатилган.

Статистик маълумотларни тахлил қиладиган бўлсак, бугунги кунда мазкур сохага нисбатан ахолининг эхтиёжлар юқори бўлса-да, бироқ эксперткриминалистика бўлинмалари томонидан пуллик асосда кўрсатилган хизматларнинг хажмини кам эканлигини кўриш мумкин. Бунга хуқуқни кўллаш назарияси ва амалиётида бир неча омиллар сабаб бўлмоқда. Хусусан, "Ўзбекистон Республикаси Ички ишлар вазирлиги бош маркази тўғрисида"ги Низомга мувофиқ экспертиза, илмий-тадқиқот ва ахборот хизматларини тақдим этиш фақатгина юридик шахсларгагина кўрсатилиши мазкур соха фаолиятини маълум бир чекловларига сабаб бўлмоқда. Хуқуқни қўллаш амалиётида жисмоний шахслар томонидан келиб тушаётган мурожаатлар бўйича хизмат кўрсатиш юқорида кўрсатилган норматив-хуқуқий хужжатда назарда тутилмаган. Чунки “жисмоний шахсларга мазкур фаолиятда пулли хизматлар кўрсатилса, салбий тусдаги хуқуқий оқибатлар келиб чиқиш холатлари вужудга келиши мумкин”, деган қарашлар мавжуд.

Айни пайтда, ривожланган давлатларнинг аксарият қисми Европа судэкспертиза институти тармоғлари (Тhe European Network of Forensic Science Institute)2га аъзо бўлган. Мазкур ташкилот томонидан 17 хил суд-экспертиза

\footnotetext{
${ }^{2}$ Изох. Европа суд-экспертиза институтлари тармоғи (ENFSI) суд-экспертиза сохасидаги ўзаро маълумот алмашишни такомиллаштириш мақсадида 1995 йилда ташкил етилган. Мазкур ташкилот Сифат ва ваколатларни бошқариш, илмий-тадқиқот ва ишлаб чиқариш, таълим ва ўқитиш сохаларидаги умумий ишлардан ташқари, 17 хил суд экспертизалари эксперт ишчи гурухлари томонидан олиб борилади. Ташкилотнинг 2019 йил хисобига кўра 71 аъзоси бўлиб, жумладан, Австрия, Арманистон, Озарбайжон, Белгия, Болгария, Хорватия, Кипр, Чехия, Дания, Естония, Финляндия, Франция, Грузия, Германия, Греция, Венгрия, Ирландия, Италия, Латвия, Литва, Собиқ Югослав Республикаси Македония, Малта, Черногория , Голландия, Норвегия, Полша, Португалия, Руминия, Россия, Сербия, Словения, Словакия, Испания, Швеция, Швейцария, Туркия, Украина ва Буюк Британия каби давлатлардан иборат. htpp//www.enfsi.eu
} 
хизматлари, жумладан бармоқ изи хизмати (fingerprint services) ${ }^{3}$, ўқотар қурол ва ўқотар қурол қолдиқлари хизмати (Firearms/GSR) ${ }^{4}$, ёнғин ва портлашни ўрганиш (Fire and Explosion) 5 ва бошқа кўплаб турдаги суд-экспертиза хизматларини тақдим этади. Шуни алохида таъкидлаш мумкинки, ушбу ташкилотга аъзо давлатларда суд-экспертиза, криминалистика сохасига оид алохида институтлар ташкил этилганлигини кўриш мумкин. Жумладан, АрманистонМиллий тажрибалар бюроси,АвстрияЖиноят-разведка хизмати ва Суд тиббиёти хизмати, БельгияМиллий криминалистика ва криминология институти, БолгарияСудтиббиёт ва криминология илмий-тадқиқот институти, КипрКриминалистик хизматлар Кипр полицияси, ФранцияГендамерие суд-тиббиёт институти, ГерманияФедерал жиноят полицияси,Висбаден Суд-тиббиёти институтларини келтириш мумкин. Хусусан, Россия Федерацияси Ички ишлар вазирлиги экспертиза-криминалистика маркази жисмоний ва юридик шахслар учун шартнома асосида экпертиза хизматларини тақдим этади.

А.В.Горелик таъкидлаганидек, экспертиза муассасалари жисмоний ва юридик шахслар учун шартнома асосида эксперт тадқиқотларини ўтказиш, фуқаролик, маъмурий ва хакамлик судлари, маъмурий хуқуқбузарлик холатлари буйича суд экспертизаларини ўтказиш учун хақ олиш хуқуқига эга. Ушбу маблағларни сарфлаш тартиби тегишли федерал органлар томонидан белгиланади.

Хиндистоннинг Халқаро суд-экспертиза институти (IFS Education Dept. International Forensic Science Institute) анъанавий таълим хамда масофавий онлайн таълим тизими орқали экспертиза сохаси билан боғлиқхизматларни хақ эвазига ўқитишни йўлга қўйган. Мазкур институтда 30 дан зиёд экспертиза хизмати билан боғлиқ сохаларни 2 ойлик (қисқа муддатли сертификат 200 АҚШ доллари), 6 ойлик (мураккаб сертификат 300 АҚШ доллари), 12 ойлик (ПГ сертификати 500 АҚШ доллари, Профессионал ихтисослаштирилган сертификатлаш 750 АҚШ доллари, умумжахон сертификатлаш 900 АҚШ доллари) таълим жараёнида XXI асрнинг ўзгарувчан дунёсини махаллий, миллий ва глобал даражада тушуниш ва самарали иштирок этиш учун билим ва кўникмалар беради.

Беларусь, Украина, Туркия, Татаристон, Франция, Германия, Россия Федерацияси Ички ишлар вазирлиги экспертиза-криминалистика марказлари хам жисмоний ва юридик шахслар учун шартнома асосида экпертиза хизматларини тақдим этади. А.В.Горелик таъкидлаганидек, экспертиза муассасалари фуқаролар ва юридик шахслар учун шартнома асосида эксперт тадқиқотларини ўтказиш,

\footnotetext{
3 Изох. Бармоқ излари хизматлариБармоқ излари хизмати гурухининг вазифаси хуқуқбузарлар, ўқотар қуроллар лицензиясидан даъвогарлар, ўйин комиссияси аризачилари ва керак бўлганда бошқа одамлардан олинган бармоқ излари тўғрисидаги маълумотлар базасини сақлашдир.Ходимлар илгари бармоқ излари бўлган хуқуқбузарларни, номаълум мархумларни ва авария қурбонларини, шу жумладан йирик табиий офатларда иштирок етганларни аниқлайдилар.Бармоқ излари хизмати гурухи, шунингдек, яширин бармоқ излари - кўзга кўринмайдиган бармоқ изларини текшириш, шунингдек, жиноятчилик жойларидан тикланган яширин бармоқ изларини ўрганиш ва аниқлаш орқали жиноятларнинг тергов қилинишига ёрдам беради

${ }^{4}$ Изох. Ўқотар қурол ва ўқотар қурол қолдиқлари хизмати (firearms /FA/, gunshot residues /GSR/) 1995 йилда Рижсщижк шахрида ташкил этилган бўлибўқотар қуролларни идентификациялаш, ўқотар қуроллар техникаси, ўқотар қолдиқлари ва ўқотар қуроллар хуқуқбузарлигида жиноятчиликни қайта тиклаш сахналаридаги илмий тажрибаларни бирлаштиради.

5Ёнғин ва портлашни ўрганиш бўйича хизмати дала текшируви, техник тадқиқотлар ва ёнғин содир бўлган жойни кимёвий тахлил қилиш.
} 
фуқаролик, маъмурий ва хакамлик судлари, маъмурий хуқуқбузарлик холатлари буйича суд экспертизаларини ўтказиш учун хақ олиш хуқуқига эга. Ушбу маблағларни сарфлаш тартиби тегишли федерал органлари томонидан белгиланади. Ушбу меъёр аслида Россияда эксперт бизнесининг жуда мухим элементини белгилайди ва суд экспертига, давлат суд-тиббиёт муассасаларига эксперт хизмати бозорига кириш имконини беради.

Суд амалиёти шуни кўрсатадики, фуқаролар ва юридик шахслар учун шартнома асосида тадқиқотлар одатда инсон саломатлигига етказилган зарарнинг табиати ва оғирлигини аниқлаш учун ўтказилади. Жумладан, етказилаган зарар оқибатида мехнат қобилиятини йўқотиш даражасини белгилаш, айрим холларда, жинсий яхлитликни аниқлаш мақсадида ўтказилади. Шу боисдан, мамлакатимизда эксперт-криминалистика бўлинмалари томонидан жисмоний шахсларга хам экспертиза, илмий-тадқиқот ва ахборот хизматларини тақдим этишда хуқуқий оқибат келтириб чиқармайдиган хизматлар доирасини аниқлаган холатда хизмат кўрсатишни йўлга қўйиш мумкин, деб хисоблаймиз. Жумладан:

- ўзини химоя қилиш қуроли бўйича; 6

- компьютер технологияси сохасида хизмат ва маслахатлар кўрсатиш, хусусан рақамли ташувчиларда ўчиб кетган маълумотларни қайта тиклаш ва рақамли маълумотларни химоялаш бўйича; ${ }^{7}$ бўйича 8 .

- заргарлик буюмлари ва вино-ароқ махсулотлари таркибини аниқлаш

Шу билан бирга, ушбу сохада хизматлар кўрсатиш доирасини кенгайтириш мақсадида хуқуқни мухофаза қилувчи органлар билан хамкорликда хуқуқий тарғибот ишларини тизимли равишда амалга ошириш зарурияти мавжуд.

Айни пайтда, ички ишлар органларининг эксперт-криминлистик бўлинмалари томонидан юридик шахсларга пуллик асосда экспертлик, илмийтадқиқот ва ахборот хизматларини тақдим этиш амалиётини тахлили сохада ўз ечимини кутаётган бир қатор масалалар мавжудлигини кўрсатмоқда. Чунончи:

биринчидан, корхона, ташкилот, муассасаларда, айниқса банкларда қалбаки пулларни қабул қилиш холатларининг хам учраётганлиги, бу борада ходимларнинг қалбаки хужжат белгиларини аниқлашга оид билим ва малакаларининг етарли эмаслиги кузатилмоқда.

Фикримизча, ИИВ Эксперт-криминалистика бош маркази ва унинг худудий тузилмалари, ИИВ Академияси, Малака ошириш институти томонидан мутасадди ташкилотлар, шу жумладан тижорат банклари билан шартнома асосида уларнинг ходимларининг хужжатлар, қимматбахо қоғозлар, шахсни тасдиқловчи хужжатлар

\footnotetext{
${ }^{6}$ Изох:Ўзини химоя қилиш қуроли билан содир этилган жиноят жойларидан олинган ўқ ва гилзаларнинг отган қурол ва унинг эгаси хақидаги ахборотни экспертиза маълумотлар базасидан топишнинг юқори тезлик ва аниқлик даражасини йўлга қўйиш хамда терговчи ва одил судловнинг мехнат самарадорлигини ошириш, ходимларнинг ортиқча иш вақтини тежаш мақсадида. ЭКБ томнидан Ўзбекистон фуқаросига тегишли бўлган ўзини химоя қилиш қуроли бир йилда бир марта назорат тартибида отилади ўқ ва гилзалардан намуналар олинади.

${ }^{7}$ Изох: Жисмоний шахсга тегишли бўлган телефон, компьютер, флеш-карта каби ахборот ташувчи техникалардаги ўчиб кетган маълумотларни қайта тиклаш мақсадида мазкур хизмат кўрсатилиши мумкин.

${ }^{8}$ Изох: Мазкур турдаги экпертлик тадқиқотлари кўп холатларда иқтисодий, фуқаролик хуқуқий муносабатлар доирасида тайинланиши сабаб мижозлар аксарият холатларда жисмоний шахслар бўлиши мумкин.
} 
хамда пулларнинг қалбакилаштириш белгилари бўйича билим ва кўникмаларини оширишга қаратилган таълим хизматларини хақ эвазига кўрсатиш тизимини жорий этиш лозим.

иккинчидан, маълумки, хужжатлар, қимматбахо қоғозлар, лотерея чипталари, шунингдек бошқа турдаги қатьий хисобот остидаги босма махсулотларнинг хақиқийлигини аниқлаш бўйича тадқиқотлар, қўлёзмалар ва имзоларни идентификация қилиш буйича тадқиқот хамда узоқ муддат мобайнида ўчиб кетган матнларни қайта тиклаш тадқиқотлари одатда жиноят, иқтисодий, фуқаролик ва маъмурий ишлар доирасида тайинланиши сабабли судларнинг экспертиза тайинлаш тўғрисидаги ажрими асосида экспертиза харажатлари томонларнинг бирига юкланади.

Аммо, мазкур турдаги ишларни амалга оширишда суриштирувчи, терговчи ёки прокурор пуллик экспертиза хизматини кўрсатиш бўйича қарор ёки хулоса бериши қонун хужжатларида белгиланмаган.

Фикримизча, судларнинг электрон почта манзилларига ИИВ Эксперткриминалистика бош маркази ва унинг худудий тузилмаларининг пуллик хизмат кўрсатиш шартлари ва имкониятлари тўғрисида батафсил маълумот юбориш тизимини жорий этиш лозим.

учинчидан, Ўзбекистон Республикаси Ички ишлар вазирининг 2017 йил 3 июлдаги 125-сонли буйруғи билан “Ички ишлар органларининг эксперт-криминалистик бўлинмалари томонидан юридик шахсларга пуллик асосда экспертлик, илмий-тадқиқот ва ахборот хизматларини тақдим этиш тартиби тўғрисида"ги Низом тасдиқланган бўлиб, унинг 21-бандига кўраЭКБ базасида пуллик хизмат кўрсатиш бўйича буюртма қабул қилинган тақдирда, буюртмачи томонидан бажарувчи хисоб рақамига, шартномада кўрсатилган сумма (пул) миқдорининг 15 фоизи олдиндан амалга оширилиши, буюртма бажарилганидан сўнг, буюртмачи қолган 85 фоиз миқдоридаги тўловни амалга оширилиши белгиланган.

Назаримизда, мазкур тартибни амалга ошириш жараёни инсон омили мехнатининг хамда вақтининг ортиқча сарфланишини келтириб чиқармоқда. Шу боис тўловни “Click" хизмати орқали амалга ошириш тизимини жорий этиш фойдадан холи бўлмайди.

\section{Фойдаланилган адабиётлар рўйхати}

1. Мирзиёев Ш.М. Эркин ва фаровон демократик Ўзбекистон давлатини биргаликда барпо этамиз. - Т.: Ўзбекистон, 2016. Б. 15-16

2. Ўзбекистон Республикаси Президентининг 2017 йил 18 апрелдаги «Ички ишлар органларининг жиноятларни тергов қилиш сохасидаги фаолиятини тубдан такомиллаштириш чора-тадбирлари тўғрисида»ги Пқ-2898-сонли карори // Ўзбекистон Республикаси қонун хужжатлари тўплами, 2017 й., 17-сон, 290модда.

3. Ўзбекистон Республикаси Ички ишлар вазирлиги Эксперткриминалистика бош марказининг архив материалларидан. - Т., 2019 йил 10 декабрь. 
4. Горелик А.В. Является ли экспертиза в производстве по делам обадминистративных правонарушениях судебной? // Вестник Сибирского юридического института ФСКН России. - С.151.

5. www.ifs.edu.in/scope-career/

6. ГореликА.В. Ўша манба. - С.151 